\title{
Lessons in Reality: Teaching Project Management, Professionalism and Ethics to Third Year IT Students
}

\author{
Vicky Wilson \\ Edith Cowan University, Perth, Western Australia.
}

\begin{abstract}
It is widely accepted amongst tertiary educators that IT students need first hand experience of working in teams and in managing projects if they are to be effective in the workplace. In 2001 the School of Computer and Information Science at Edith Cowan University undertook a major restructure of its courses that resulted in the development of eight 'core' units that are taught in a range of courses across the School. One of these was a third-year unit called 'Project Management, Professionalism and Ethics'. This case study documents the research that was undertaken to determine the unit content and its subsequent development and delivery. It discusses the formal and informal feedback received from students and staff after its delivery in semester 2, 2001 and what will be done to develop the unit into a fully integrated online 'situated learning' experience.
\end{abstract}

Keywords: Situated learning, IT education, learning theory, course design and delivery.

\section{Introduction}

It is widely accepted amongst tertiary educators that IT students need first hand experience of working in teams and managing projects if they are to be effective in the workplace. Situated learning, in which knowledge is gained in the context of authentic problem situations, can help learners acquire expert "tricks of the trade," while mastering program content (Wright, 2000). With the assistance of an internal grant of A \$10,000.00, work began at Edith Cowan University (ECU) in 2001 on the process of developing a situated learning framework for what will eventually be an web-based project management education unit for third year IT students. The unit is titled 'Project Management, Professionalism and Ethics' (PMPE).

\section{Background}

In 2001 we were charged with developing a new 'capstone' unit that would be core in the third year of all of our IT courses. The reasons for developing this unit were various. Firstly, the students had encountered some of the tools of project management earlier in their courses but they required an overall conceptual understanding of IT project management and its associated tools and techniques. Secondly, they needed to sharpen their business, professional and social skills prior to entering the workforce. Thirdly, the IT professional associations have demanded that greater emphasis be given to the ethics of professional practice and this unit offered an opportunity to address these issues within a meaningful context.

Material published as part of these proceedings, either on-line or in print, is copyrighted by Informing Science. Permission to make digital or paper copy of part or all of these works for personal or classroom use is granted without fee provided that the copies are not made or distributed for profit or commercial advantage AND that copies 1) bear this notice in full and 2) give the full citation on the first page. It is permissible to abstract these works so long as credit is given. To copy in all other cases or to republish or to post on a server or to redistribute to lists requires specific permission from the publisher at Publisher@InformingScience.org
Making the unit core to all our IT courses meant that we had a large number (207) and a broad range of third year undergraduate students taking the unit in 2001. Students were enrolled in courses that ranged from the 'harder' technical end of the scale - the software engineers and the computer scientists - to the 'softer' courses, where students might be pursuing an interest in IT combined with topics as 
diverse as interactive multimedia, management, marketing, library technology, archives and records management.

With any form of information or knowledge, providing students with access to meaningful content does not guarantee learning. What is also important to learning are the levels of learner engagement and often these are influenced by factors outside the domain of materials design. It appears in many settings where WWW-based learning materials are used for teaching and learning that the most consideration and thought is given to materials design and the least consideration and thought is given to the ways in which the materials will be implemented. The roles of the teacher and students are often considered less important than the materials themselves. (Oliver, Omari, \& Herrington, 1998).

We not only needed to provide a rich online learning environment in terms of the design and delivery of the materials, but also implement those materials in such a way that the students would have 'legitimate peripheral participation' in a 'community of practice' through the development of a 'situated learning' framework (Herrington \& Oliver, 2000).

Designing such a framework in a University setting is not necessarily an easy task. The first challenge was that, as there were going to be in excess of 200 internal $3^{\text {rd }}$ year students enrolled in the unit in 2001 and the University is yet to provide a fully integrated online learning environment, we had to develop a framework where the learning materials were provided online but with face-to-face delivery and management of student progress. At the same time, we wanted to ensure that whatever was compatible with eventually developing an truly online learning environment where the physical location of the students is irrelevant.

Using internal grants, the learning materials were developed in 2000 and now take the form of a website organised into weekly sections:

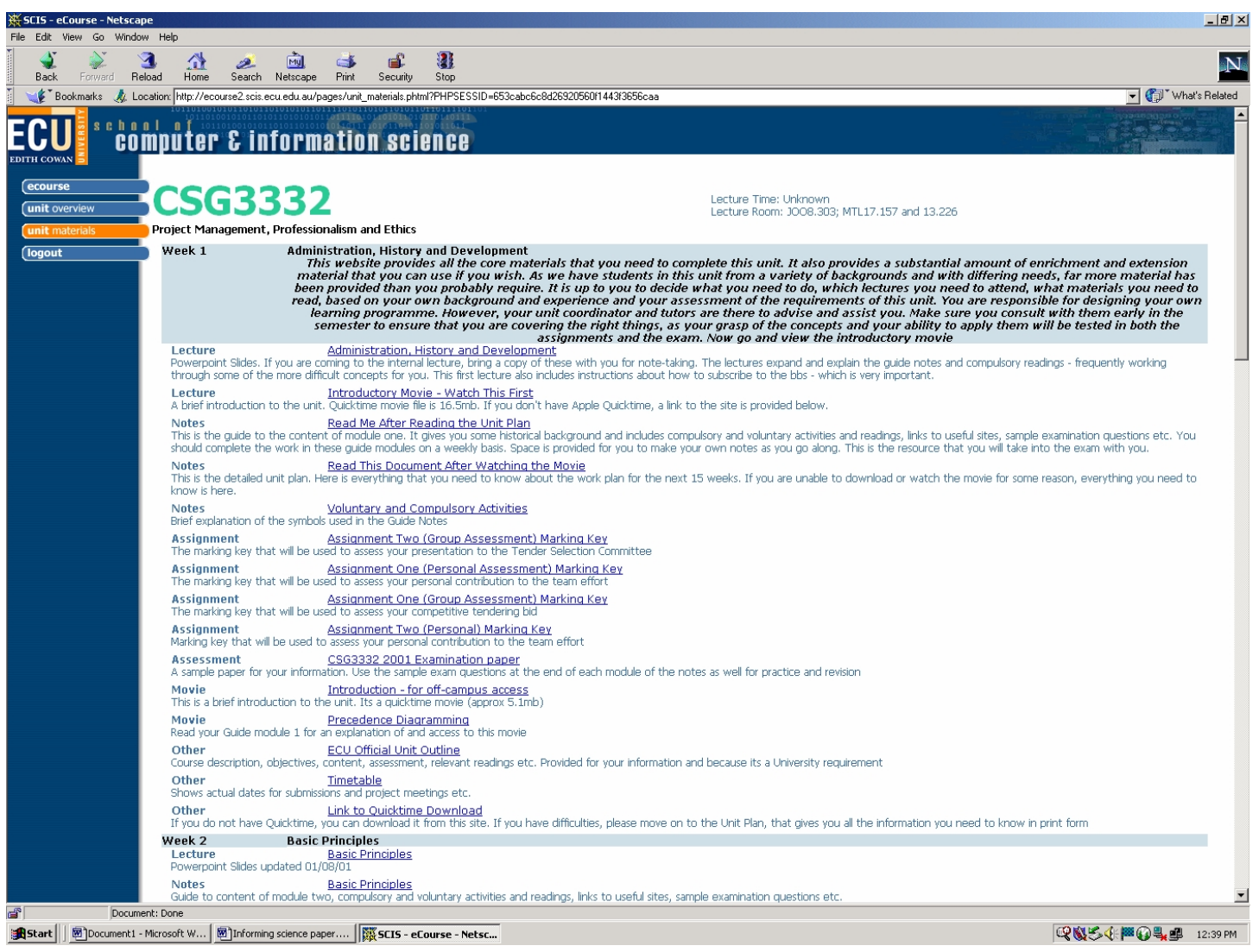


Each week has a 'guide' based around a textbook, that introduces the concepts and provides a series of reinforcement exercises and enrichment activities, including some interactive multimedia components such as the animation shown below (Wilson \& Terry, 2000):

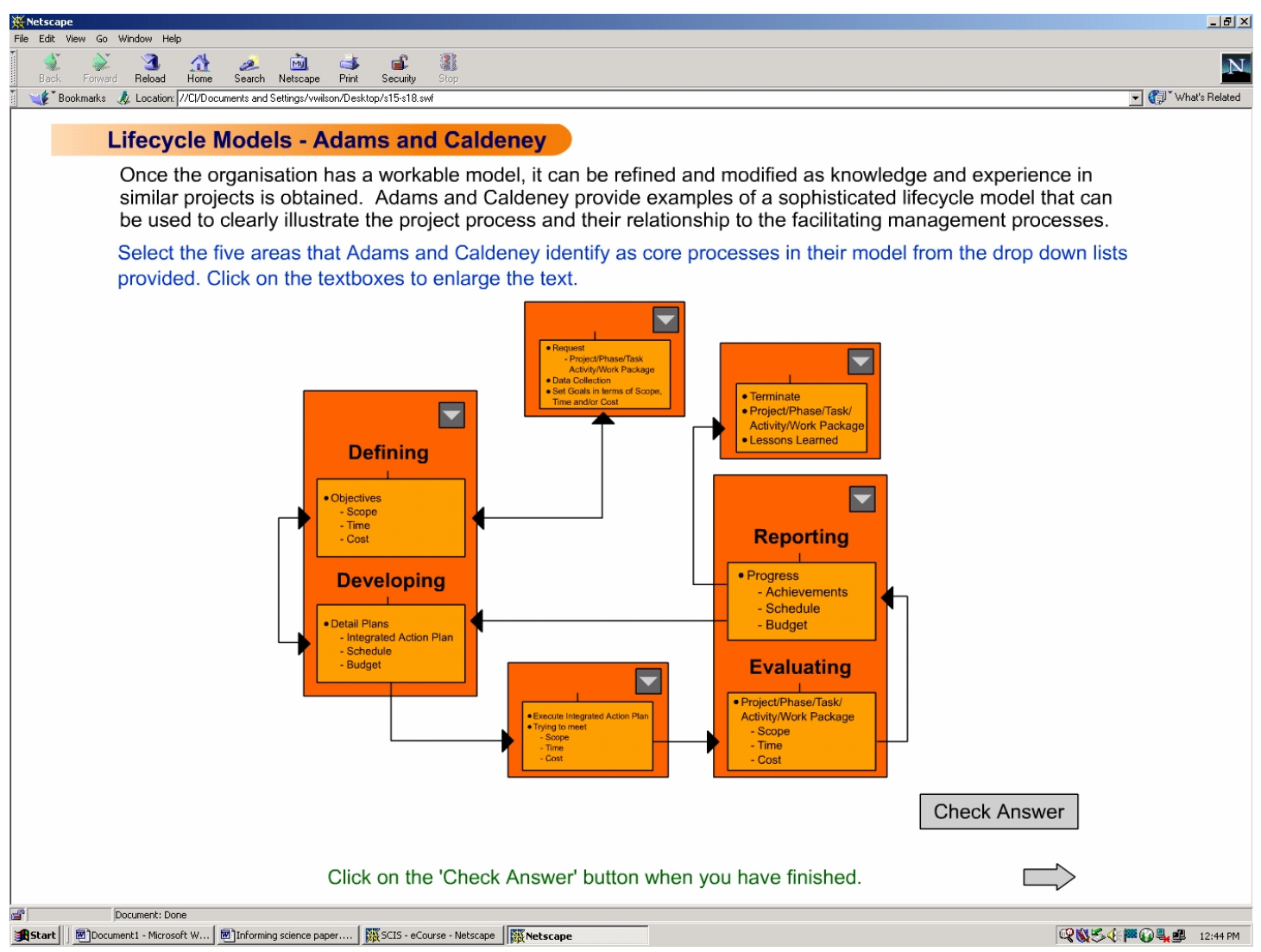

Other resources include Powerpoint lecture slides, links, online chat facilities and bulletin boards. The unit is controlled by a delivery plan for the semester that includes weekly face-to-face mass lectures, selfpaced voluntary laboratories and a project meeting schedule for tutors and teams (Attachment 1).

\section{'Situated' Learning}

'Situated learning' is 'a social, dialogical process in which communities of practitioners socially negotiate the meaning of phenomena" (Jonassen et al., quoted in Lueddeke, 1999, p. 236). 'Situated learning' is a concept that 'recognises the value of contextualising learning within settings which reflect the purpose of learning and how learners might ultimately apply this learning beyond the classroom'(Oliver, Herrington, \& Omari, 1999, p. 2). It is a social constructivist learning philosophy that contends that 'the materials must engage the learners and support cognitive processing leading to knowledge construction (Reeves, quoted in Oliver et al., 1998, p. 122). Importantly, situated learning recognises that interaction and socialisation among learners are critical to the learning process (Oliver et al., 1999, p. 2).

In designing any flexible learning environment, Oliver, Herrington and Omari advocate selecting a 'problem-based' approach. This type of approach:

'...helps the learner frame experience as a series of problems to be solved and where the process of learning unfolds through the application of knowledge and skills to the solution of real world problems' (Bligh, quoted in Oliver et al., 1999, p. 3). Problem-based approaches increase student motivation, develop critical thinking skills and deepen understanding of significant content (Oliver et al., 1999, p. 4). 
In a three-part study conducted in 2000, Jan Herrington and Ron Oliver identified the critical characteristics of a situated learning environment, operationalised those characteristics and investigated student perceptions of their experiences in using that learning environment. They identified nine non-sequential elements of a situated learning framework that they recommend are used by designers to develop a model based on constructivist values and recent learning theory. They are:

- Provide authentic contexts that reflect the way the knowledge will be used in real life

- Provide authentic activities

- Provide access to expert performances and the modelling of processes

- Provide multiple roles and perspectives

- Support collaborative construction of knowledge

- Promote reflections and enable abstractions to be formed

- Promote articulation to enable tacit knowledge to be made explicit

- Provide coaching and scaffolding by the teacher at critical times

- Provide for authentic assessment of learning within the tasks

In developing PMPE, we took this framework and developed a teaching model based on these nine characteristics. What follows is a discussion of how this was done and the reaction of both the staff and students to the delivery of the unit in the latter half of 2001.

\section{Authentic Context}

'Authentic context is the cornerstone of the situated learning model' (Herrington \& Oliver, 2000). When PMPE was originally being developed, we gave considerable thought to selecting an activity that the students would, in all likelihood, encounter soon after entering the workplace. We also wanted to design an activity that would allow them to practise high-level business, managerial and problem solving skills in an interactive, team-based setting.

The activity we chose was a partial response to a 'Request for Proposal' (RFP). The RFP used was for the installation of a turnkey document management system for a large Western Australian government agency that was issued in 1999. The agency concerned supplied the original tender document and the local reseller for the winning software solution gave us permission to use their name and website and provided background information on how the winning response had been developed. The students were provided with a copy of the original RFP and were told:

'You are a small independent group of computer consultants. You are the official resellers for Tower Software's product TRIM. You also provide on-site software and hardware support for the product in North-West State. You have been in business for six years and are managing to hold your own in a very competitive market. Your major clients are Cooperative Grain Handling, The Water Corporation and the Ministry of Premier and Cabinet. The Manager: Corporate Information in the Ministry of Premier and Cabinet has been pleased with the level of service and support that you and Tower Software have offered over the past four years, so you have some advantage over your competitors. However, this is the first time that you have tendered for such a comprehensive document management system and it does present you with some challenges, not least of which is the small size of your local team - there is only yourself as manager, two customer support consultants and a secretary/receptionist... 


\section{Authentic Activity}

The activity was complex and required considerable planning and sustained thinking over a number of weeks to complete. At first glance it appeared as if the assignment had quite a tight structure, in that the students had to respond to specific questions posed in the tender document. However, on closer examination the students realised that, to answer the questions effectively they had to grapple with some unfamiliar, unstructured issues associated with 'real world' project management, including breaking down complex tasks into work packages, delegation, outsourcing of work to third parties, dealing with contractual and legal issues, adhering to quality standards, identifying and managing risk events, etc.

To make the whole exercise as realistic as possible, the students were also told that they were in a competitive bidding environment so that, in order to achieve the highest mark and 'win' the tender, they would have to develop a credible and cost effective implementation plan, without knowing what the other teams were doing. In addition, they had to work all these issues through in a team environment with other students from different courses, whom they did not know and who brought different skill sets to the team.

Once the details of the assignment had been explained to them, the reactions of the students ranged between amusement and panic. They accepted, on the whole, that the assignment was authentic, but the initial reaction that they did not have the experience, nor the in-depth technical understanding, to respond effectively. In order to assess the effectiveness of this new teaching strategy, all the students in the unit were canvassed at the end of the semester, using the University's standard unit and teaching evaluation instruments (University, 2002). While most indicated that they had overcome these initial problems by the end of the semester, for some it remained an issue:

'I found the assessment very difficult as I felt it required too much intimate knowledge to complete successfully' (Review, 2001).

We recognised that the task was challenging and that, in a situated learning framework such as the one we were trying to design, the students would need considerable support. Several strategies were adopted. The most important was to provide the students with access to expert performances and to the modelling of the processes required.

\section{Expert Performance}

It proved very difficult to provide the students with tutors who were expert practitioners. One reason for this is the fact that experienced IT project managers are in great demand, earn large salaries and are normally too busy to take time out to tutor university students. Also, university pay scales for sessional tutors are not conducive to attracting experienced professionals. As a result, scouring our personal and industry networks proved fruitless. However, we were lucky in that we were able to find four experienced IT project managers who were already working for the University in a variety of capacities and who agreed, as a service to the University and the students, to take on these roles.

The tutor's major role was to act as the senior project manager and advisor to each of the project teams. A roster of project meetings was established and students were encouraged to consider the tutor as a mentor and a resource, to be contacted whenever problems arose. This strategy worked well, with students feeding on the real life experiences of the tutors and learning from the 'warts and all' stories that these practitioners had to tell. My role, as unit coordinator and lecturer, was to act as the client and contact point for general questions. The students quickly realised that I was another useful resource on questions of detail as well, although I had to be careful that I did not advantage one group above another. As the semester progressed, the flavour of the unit developed rapidly to one of 'Well, this is what the textbooks tell you, now this is what happens in real life...' 
The tutors also had the role of modelling appropriate supervision behaviours, such as running project meetings and requiring documentation with action points and responsibilities. They closely watched the performance of the teams and the individual team members. They were assigned $20 \%$ of each student's mark to assess personal professionalism, ethical standards and leadership and team behaviours.

\section{Multiple Roles and Perspectives}

The students met with their tutors in groups of 20 at a time and were organised into teams of between 4 and 6 individuals in the first week of semester. Most were not allowed to choose the composition of their teams, but were mixed so that the team contained at least one software engineering student, one computer science student, one communications and information technology student and at least one native English speaker. The last criterion was important as there were a very high proportion (over $40 \%$ ) of international students.

The final composition of the teams met with a mixed response from students. For some it was a challenge to improve their performance because they were out of their comfort zone. Others found it interesting and thought provoking to be with peers from different disciplines. New friendships were formed in groups that worked well. Some experienced difficulties. A number wanted to work with their friends and found it difficult to overcome their shyness. A common comment was the time it took for the team to coalesce and reach the 'performing' stage: '... a lot of time was spent getting the group to 'gel' before any work was done'(Review, 2001). In general, the older and more experienced the team members, the quicker they managed to settle to the task.

The students provided a range of views and perspectives to the problem because they came from differing disciplines and differing cultural backgrounds. Some conflict occurred because of these differing perspectives, and because of differing interpretations and differing approaches to problem solving. Tutors had to work hard to address some of these interpersonal problems and valuable lessons were learnt about cultural tolerance, ethical behaviour, negotiation, listening, respect and professional commitment within the teams.

Students normally dislike group work because they have no power to force indolent members of the team to perform. The structure that we adopted went some way to solving this problem because the real power resided with the tutor and there were significant penalties for not performing. When evaluating the unit, one student commented:

'I hate group work as there are too many slackers. But the new assessment system helped overcome these difficulties i.e. give recognition to individual effort' (Review, 2001)

The students were encouraged to reflect on the application of the principles taught in the lectures using their team experience in this unit, leading to some interesting, if slightly heated, discussions either during the lecture, or in small groups after class or in my office. It also helped that the software engineering and computer science students were involved in software development projects at the same time as they were doing this unit, so many 'war stories' came back about the difficulties they were experiencing in working in these other teams, which served to reinforce the human perspectives that we were emphasising in this unit.

\section{Collaboration}

The team structure encouraged a collaborative learning environment but the size of the teams was a problem. For teams that worked well together the comments were positive: 
'I enjoyed working with my team and it meant that we could get the work done - it would have been far too hard on my own. You have to be prepared to back down sometimes though...' (Interview with student, November 2001)

Most teams appointed a group leader although they were not encouraged to do so as I wanted the authority to rest with the tutors. However, the groups were large (up to six people) and logistically it was a sensible thing to do. This person took on the role of coordinating the effort of the group and was pivotal in determining the team members' perceptions of the collaborative process:

'....was great! He worked really hard and really motivated us to do our best work.'(Email communication with student, November 2001)

'...Oh Vicky, it was a disaster! ...I really understood all that stuff about the importance of leadership skills...he was really terrible!' (Personal conversation with a Communication and IT student, October 2001)

Collaboration was encouraged by the fact that the teams independently determined the gaps in their knowledge and also decided which of their team members would acquire the necessary skills, based on the work that they were doing. All the instructional materials and information was available from the website and the teams knew where to go to find it if they needed it. For instance, Microsoft Project was made available but no tuition - apart from an introductory workshop - was given. Online training in a range of areas was available using NetG (NetG, 2001) products (see attachment 1) and links were created to 'realworld' sites that provided sample tender documents, government tendering instructions, assistance with project management tools etc.

Students were encouraged from the beginning to take responsibility for their own learning. The theory and concepts were covered in detail in the lectures and backed up by extensive notes and enrichment materials on the website. No prior knowledge was assumed. However, students were told in the first week that far more material was being made available than they could possibly absorb in fifteen weeks and only the individual could decide what he/she needed to cover and in what depth. They were encouraged to make informed choices about what lectures they attended and what materials they used, based on their own past experience and own assessment of their learning needs. The sting in the tail was the fact that they would have to demonstrate their theoretical and conceptual competence in the final, 'restricted open book' exam. Many students found this quite threatening. One remarked '....I wanted more structure and guidance so that I could feel a sense of achievement and satisfaction'.(Review, 2001) Others found it liberating: 'A really sensible approach that allowed me to do what was required without 'busy' work' (Interview with student, November 2001)

\section{Reflection}

Boud, Keough and Walker (quoted in (Herrington \& Oliver, 2000)) define reflection as intellectual and affective activities that lead to new understandings and appreciations. Evidence of reflection in this unit surfaced mostly in the conversations held in the lectures, where interaction was encouraged, significant amounts of small group work was conducted and students contributed experiences and anecdotes as various points were raised. It was also evident in comments made by students directly to me, for instance:

'We need to take this unit before we start our major third year projects. If I had known then what I know now about project management, the whole exercise would have been far less stressful.' (Personal conversation with Software Engineering student, October 2001).

'I was made project manager at and it was a disaster because I had no authority over the other team members and had to deal with people much higher up the organisation, who ignored me. Had I 
known how all this works at that time, it would have been very different - I'd have refused the job!' (Personal conversation with Software Engineering student, October 2001).

\section{Articulation}

The students articulated their understanding of the project implementation and tender process through the second assessment, which was a Powerpoint presentation and 'question and answer' defence of their submission to a selection panel of 'ministry' personnel. To improve the authenticity of the experience, the teams had to answer specific questions that probed perceived weaknesses or ambiguities in their response, just as they would have to do if they had been short-listed in real life.

Originally it was hoped that the entire teaching team of five could view all 36 presentations, but the tutors could not afford the time, so the teams presented just to myself and their tutor. Once again, the mark for this assignment was divided to assess both individual and group performance.

\section{Coaching and Scaffolding}

A major early concern of the students was the complex and ill-structured nature of this authentic assessment and the lack of specific direction and guidance as to how to tackle the problem. As I was fully familiar with the programme and its possibilities, I briefed the tutors prior to the commencement of the semester on their coaching and scaffolding role. The tutors committed to being available to clarify issues and answer questions not only in the scheduled project meetings but also via telephone and email. I also made myself freely available to students and guaranteed a 24 hour turnaround on any request for assistance. This proved to be a major time commitment for us all, especially early in the semester, as the students came to grips with the nature of the work.

At the beginning of each lecture there was an opportunity for comment and questions and after lectures the students also had the opportunity to clarify things with me personally. A bulletin board was established where all the tutors contact details were posted and where students could post questions and where discussion threads were established on points of detail.

In the scheduled project meeting part of the tutors' role was to determine how much progress had been made and to assist the team to develop a more in-depth understanding of what was required, through examination of the details of their work. Students responded to this in a variety of ways. Overall, the reaction of the students to the level of support and scaffolding provided was positive (scoring a 3.35 on a five point scale $(\mathrm{N}=90)($ Review, 2001)). Some of the teams were very proactive and prepared agendas, took minutes and had a series of prepared questions for their tutors. These teams found the progress meetings positive and helpful and reported that it was valuable to be able to discuss and reflect on the detail of what they were doing. Others teams were more passive, less well prepared and generally more negative about the experience. Comments from these groups included:

'No clear direction in the beginning, a lot of time wasted barking up the wrong tree'

'We shouldn't have to do a tender project, the workload is too heavy considering the other ... unit is also a large group project ...'

'I found the assignment to be an exercise in frustration...This tender document was a poor exercise ...'(Review, 2001)

The tutors gave freely of their time but lack of familiarity with the unit and the tender document did lead to some inconsistency in the advice given. Some students expressed dissatisfaction on this point: 
'The info given by the tutor was often misleading and in conflict with the info given by the lecturer'(Review, 2001)

Generally, the feedback on the level of support and scaffolding offered by the teaching team was positive, with evaluation scores for these criteria scoring 3.985 on a 5 point scale $(\mathrm{N}=112)($ Review, 2001)

\section{Authentic Assessment}

The entire structure of the assessment in this unit was designed as a simulation of an activity that they were likely to be involved in real life. On the whole, students appreciated the practicality of what they were being asked to do (positive 3.21 on a 5 point scale $(\mathrm{N}+90))($ Review, 2001) and felt that it was a worthwhile exercise (positive 3.12 on a 5 point scale $(\mathrm{N}=90)$ )(Review, 2001) but others could not see the point:

'Relevance to my course (computer science) should be increased'

'assignment is good for creative writing'

'The unit is irrelevant to our future careers' (Review, 2001)

There was a strong feeling that the workload was too heavy (positive 3.83 on a 5 point scale $(\mathrm{N}=90)$. This may partly be due to the difficulties of working in such large teams and also poor coordination across the third year IT programmes which resulted in considerable confusion at the beginning of the semester and many of the full time students being involved in an unreasonable amount of project work outside of this unit. The tutors were strongly of the opinion that the workload was realistic, with one dryly commenting that they had successfully completed similar tasks alone and within a few hours - just before the tender deadline.

\section{What Next?}

While the online learning materials website for this unit is now well developed, the technological infrastructure presently provided does not allow for the development of a fully functional online learning environment. The University is planning to incorporate additional functionality such as integrated chat and bbs facilities, online assignment submission and assessment tools and personalised views of the learning environment for each student. When these are available it will be possible to conduct the entire unit electronically. The lectures can be videotaped, the guide exercises and activities further enhanced using electronic quiz facilities, the project meetings conducted via chat and assessed using formative electronic assessment tools, the questions answered informally using email and formally through bbs discussion threads, the assignments submitted to a digital drop box and marked and returned in the same manner.

We are of the opinion that the structure of this unit is sufficiently robust to allow a relatively painless conversion to a full online format.

Of more concern is the articulation of this unit with the other third year units the students undertake, which, up to now, has not been done well. To this end, all the coordinators of project-based units are meeting to ensure a seamless integration of curriculum and assessment across the units. This may necessitate some changes to the assignment content in PMPE, but we are confident that the existing structure is sufficiently flexible to withstand a change of assignment and that it will continue to develop as a model for teaching IT students in this area. 


\section{References}

Herrington, J., \& Oliver, R. (2000). An instructional design framework for authentic learning environments. Educational Technology Research and Development, 48(3), 23-48.

Lueddeke, G. R. (1999). Toward a constructivist framework for guiding change and innovation in higher education. Journal of Higher Education, 70(3), 235-237.

NetG. (2001). Skillvantage manager training courses. NetG. Available: http://scisnetg.scis.ecu.edu.au/ [2001.

Oliver, R., Herrington, J., \& Omari, A. (1999). Using flexible learning approaches to create a converged learning environment for on and off-campus learners.: Copy of published paper provided by author.

Oliver, R., Omari, A., \& Herrington, J. (1998). Investigating implementation strategies for WWW-based learning environments. International Journal of Instructional Media, 25(2), 121-122.

Review, E. C. U. (2001). Student Responses to the Teaching Effectiveness Instrument for CSG332, Semester 2, 2001. Unpublished.

University, E. C. (2002). Unit and Teaching Effectiveness Evaluation Instruments, [web page]. Edith Cowan University. Available: http://www.ecu.edu.au/lift/qa/evaluation/evaluations.htm [2002, 11th February 2002].

Wilson, V., \& Terry, J. (2000, November 2001). CSG3332 Project Management Professionalism and Ethics: Guide, [Website]. Edith Cowan University. Available: http://ecourse2.scis.ecu.edu.au/pages/ecourse.phtml.

Wright, D. E. (2000). Pharmacist perceptions of situated learning in an Internet-based continuing education program. American Journal of Pharmaceutical Education, 64(4), 397.

\section{Biography}

Vicky Wilson is a lecturer in the School of Computer and Information Science at Edith Cowan University. She is the coordinator of the Master of Information Services suite of courses as well as teaching project and information services management to final year students in the School. Her research interests include improving online education for remote students, knowledge management and leadership in information service teams. She can be contacted via email: v.wilson@ecu.edu.au

\section{Attachment 1}

\begin{tabular}{|c|c|l|l|l|}
\hline \multirow{2}{*}{ Week } & Beginning & \multicolumn{2}{|c|}{ Topics } & Workshops \\
\hline 1 & 23 July & $\begin{array}{l}\text { History and De- } \\
\text { velopment }\end{array}$ & $\begin{array}{l}\text { Microsoft Project Overview and } \\
\text { Introduction }\end{array}$ & Team formation \\
\hline 2 & 30 July & Basic Principles & $\begin{array}{l}\text { Netg: Project Management } \\
\text { Fundamentals }\end{array}$ & $\begin{array}{l}\text { Brainstorming } \\
\text { Session/Meeting schedule }\end{array}$ \\
\hline 3 & 6 August & $\begin{array}{l}\text { Strategic Project } \\
\text { Planning }\end{array}$ & $\begin{array}{l}\text { Microsoft Project: Basic } \\
\text { Features }\end{array}$ & Progress meeting \\
\hline 4 & 13 August & Process Models & Netg: The Process & Progress meeting \\
\hline 5 & 20 August & $\begin{array}{l}\text { Scoping and } \\
\text { Planning }\end{array}$ & Netg: Time Management & Progress meeting \\
\hline
\end{tabular}


Wilson

\begin{tabular}{|c|c|c|c|c|}
\hline 6 & 27 August & Risk Evaluation & $\begin{array}{l}\text { Microsoft Project: Advanced } \\
\text { Features }\end{array}$ & Progress meeting \\
\hline 7 & 3 September & $\begin{array}{l}\text { Teams and Team } \\
\text { Leadership }\end{array}$ & $\begin{array}{l}\text { Netg: Project Management: } \\
\text { The Team }\end{array}$ & Progress meeting \\
\hline \multirow[t]{3}{*}{8} & 10 September & Communication & $\begin{array}{l}\text { Netg: Business Writing: The } \\
\text { Fundamentals }\end{array}$ & Progress meeting \\
\hline & 17 September & Make-Up Week & & \\
\hline & 24 September & $\begin{array}{l}\text { Mid-Semester } \\
\text { Break }\end{array}$ & & \\
\hline 9 & 1 October & Project Control & Netg: Quality Standards & Progress meeting \\
\hline 10 & 8 October & $\begin{array}{l}\text { Problem Solving } \\
\text { and Decision- } \\
\text { making }\end{array}$ & Netg: Effective Presentations & $\begin{array}{l}\text { RFP Deadline 8.30am } \\
\text { Tuesday } 9^{\text {th }} \text { October } 2001\end{array}$ \\
\hline 11 & 15 October & $\begin{array}{l}\text { Change Man- } \\
\text { agement }\end{array}$ & Presentations & Presentations \\
\hline 12 & 22 October & $\begin{array}{l}\text { Professional Is- } \\
\text { sues }\end{array}$ & Presentations & Presentations \\
\hline \multirow[t]{4}{*}{13} & 29 October & $\begin{array}{l}\text { Revision and } \\
\text { Review }\end{array}$ & Presentations & Presentations \\
\hline & 5 November & SwotVac & & \\
\hline & & Exams & & \\
\hline & & Exams & & \\
\hline
\end{tabular}

